\title{
Does Doramectin Use on Cattle Indirectly Affect the Endangered Burrowing Owl?
}

\author{
Kevin D. Floate, ${ }^{1}$ Patrice Bouchard, ${ }^{2}$ Geoff Holroyd, ${ }^{3}$ Ray Poulin, ${ }^{4}$ and Troy I. Wellicome ${ }^{5}$
}

Authors are ${ }^{1}$ Research Scientist, Lethbridge Research Centre, Agriculture and Agri-Food Canada, Lethbridge, AB T1J 4B1, Canada; ${ }^{2}$ Research Scientist, Canadian National Collection of Insects, Arachnids and Nematodes, Agriculture and Agri-Food Canada, Ottawa, ON K1A 0C6, Canada; ${ }^{3}$ Research Scientist, Canadian Wildlife Service, Environment Canada, Edmonton, AB T6B 2X6, Canada; ${ }^{4}$ Curator of Life Sciences, Royal Saskatchewan Museum, Regina, SK S4P 2V7, Canada; and ${ }^{5}$ Species At Risk Biologist, Canadian Wildlife Service, Environment Canada, Edmonton, AB T6B 2X6, Canada.

\begin{abstract}
Doramectin is one of several endectocide compounds widely used to treat nematode and arthropod pests affecting cattle. Insecticidal residues in dung of endectocide-treated cattle can reduce numbers of dung-breeding insects. Concerns have been raised that use of endectocides may adversely affect birds that rely on dung-breeding insects as food. However, these concerns have not been specifically addressed in previous studies. We performed two studies to collectively assess whether doramectin adversely affects burrowing owls (Athene cunicularia Molina), which are listed as "Endangered" in Canada. In the first study, insect emergence was monitored from dung of cattle treated with a recommended topical dose of doramectin. Experiments replicated in each of $3 \mathrm{yr}$ showed residues reduce the number of insects developing in dung of cattle treated up to $16 \mathrm{wk}$ previously. In the second study, we identified prey items from regurgitated pellets collected at 206 burrowing owl nests in southern Alberta and Saskatchewan, Canada. A total of 50213 prey items were identified, of which $90 \%$ were invertebrates. Beetles (Coleoptera) comprised $54 \%$ of the total prey items, followed next in abundance by grasshoppers (Acrididae, $20 \%$ ) and crickets (Gryllidae, 16\%). Of the beetles, 1381 specimens were identified as breeding in dung (mainly species of Aphodius, Canthon, Onthophagus). The dung beetles comprised an estimated $2.8 \%$ of the total prey items or $0.1 \%$ of total prey biomass. Results of the first study validate initial concerns that doramectin use can reduce numbers of insects breeding in dung of treated cattle. Results of the second study show reliance of burrowing owls on dung beetles is sufficiently low that use of doramectin on cattle is unlikely to appreciably affect the food supply of co-occurring burrowing owls.
\end{abstract}

\section{Resumen}

El doramectin es uno de varios compuestos endectocidos ampliamente usados para tratar las pestes de nemátodos y artrópodos que afectan el ganado. Los residuos de insecticidas en el estiércol del ganado tratado con endectocidos pueden reducir el número de los insectos encontrados en el estiércol. Existe preocupación de que el uso de endectocidos podría afectar negativamente a aves que dependen de insectos de estiércol como alimento. Sin embargo, estas preocupaciones no se han abordado específicamente en los estudios anteriores. Nosotros hemos realizamos dos estudios para evaluar colectivamente si el doramectin afecta adversamente a la lechuzita terrestre (Athene cunicularia Molina), el cual esta listado como "en peligro de extinción" en Canadá. En el primer estudio, la aparición de insectos fue monitoreada en estiércol de ganado tratado con una dosis actual recomendada de doramectin. Los experimentos repetidos en cada uno de los tres años mostraron que los residuos redujeron el número de insectos que se desarrollan en estiércol en ganado tratado hasta por 16 semanas. En el segundo estudio, nosotros identificamos ítems del pellets regurgitados de la lechuzita terrestre desde abril a finales de julio de 2004 en 206 nidos de la lechuzita terrestre en el sur de Alberta y Saskatchewan, Canadá. Un total de 50213 presas fueron identificadas, de las cuales $90 \%$ fueron invertebrados. Los escarabajos (Coleoptera) fueron el 54\% del total de presas, seguidos luego en abundancia por los saltamontes (Acrididae, el 20\%) y los grillos (Gryllidae, el 16\%). De los escarabajos, 1381 especímenes fueron identificados como insectos de estiércol (principalmente las especies de Aphodius, Canthon, Onthophagus). Los escarabajos del estiércol comprenden un estimado de $2.8 \%$ del total de las presas o un $0.1 \%$ del total de la biomasa de las presas. Los resultados del primer estudio validaron la preocupación inicial de que el uso de doramectin puede reducir el número de insectos que crecen en estiércol del ganado tratado. Los resultados del segundo estudio mostraron que la dependencia de la lechuzita terrestre en los escarabajos del estiércol es lo suficientemente baja como para que el uso de doramectin en el ganado sea poco probable que afecte sensiblemente el actual suministro de alimentos de la lechuzita terrestre.

Key Words: Athene cunicularia, endangered species, faecal residues, nontarget

K.D.F. was funded by Pfizer, Inc. and by Agriculture and Agri-Food Canada's Matching Investments Initiative (FPA A04701). R.P. was funded by the Canadian Wildlife Service-Endangered Species Recovery Fund, by Natural Sciences and Engineering Research Council, and by Alberta Ingenuity. T.I.W. was funded by Environment Canada (Prairie and Northern Region), by the Government of Canada Interdepartmental Recovery Fund, by the Biodiversity Fund (Alberta North American Waterfowl Management Plan Partnership), and by Science Horizons Youth Internship Program.

Correspondence: Kevin D. Floate, Lethbridge Research Centre, Agriculture and Agri-Food Canada, 54031 Avenue South, PO Box 3000, Lethbridge, AB T1J 4B1, Canada. Email: floatek@agr.gc.ca

Manuscript received 10 April 2008; manuscript accepted 3 July 2008. 


\section{INTRODUCTION}

More than 450 species of predacious beetles, dung-feeding beetles, flies, and parasitic wasps (on flies) breed in cattle dung on North American pastures (Blume et al. 1985). One dung pat may produce more than 1000 insects (Mohr 1943; Laurence 1954), each ranging in length from $1 \mathrm{~mm}$ to $>20 \mathrm{~mm}$. About 10 pats are deposited daily per cow (references cited in Fincher 1981). The national herds in Canada and the United States contain about 14 million (Statistics Canada 2008) and 105 million (US Department of Agriculture 2007) animals, respectively.

Given this abundance of dung, dung-breeding insects are a potentially important source of food for insectivorous birds. Dung beetles (Coleoptera: Scarabaeidae) were among the most common insects recovered from the gut contents or pellets of 128 species of British birds including various species of corvids, passerines, swifts, nightjars, herons, falcon, and owls (Newstead 1908). Dung beetles are a common component of pellets recovered from hooded crows (Corvus corone cornix L.), particularly in spring when other groups of insects (e.g., epigeic beetles) are less active (Horgan and Berrow 2004). Some species of birds that consume dung insects are of particular concern. The red-billed chough (Pyrrhocorax pyrrhocorax L.) is under special protection in the United Kingdom by virtue of its rarity (McCracken 1993). Burrowing owls (Athene cunicularia Molina) are listed as "Endangered" in Canada, "Threatened" in Mexico, and as a "National and Regional Bird of Conservation Concern" in the United States (Holroyd et al. 2001).

Birds that rely on dung-breeding insects as food could be adversely affected by agricultural practices that reduce the abundance of these insects. This concern has been raised with regard to the use of endectocides (McCracken 1993), which are a group of veterinary drugs that include doramectin, eprinomectin, ivermectin, and moxidectin. Endectocides are used globally to control nematode and arthropod parasites affecting cattle. Treated cattle excrete residues in their feces for a period of weeks or months, at levels toxic to at least some species of dung-breeding insects. Reduced emergence of insects is well documented for dung of cattle treated with ivermectin, less so for moxidectin, and much less so for eprinomectin and doramectin (most recently reviewed in Floate et al. 2005; also see Floate 2006). There will be serious implications for the use of existing endectocides and for the registration of new products if they indirectly and adversely affect birds, especially birds of threatened or endangered status. To our knowledge, no previous studies have critically assessed this issue.

Here, we address the concern that use of doramectin on cattle may adversely affect burrowing owls, which are declining in Canada and listed nationally as endangered (Committee on the Status of Endangered Wildlife in Canada 2006). Burrowing owls nest in underground burrows, preferably in pastures grazed by livestock (Poulin et al. 2005) and, therefore, often cooccur with cattle that may be treated with endectocide products. Burrowing owls also have been reported to use cattle dung as a tool to attract and enhance captures of dung beetles (Levey et al. 2004). This latter observation suggests that this species of owl has a particularly high affinity for dung beetles and, therefore, is perhaps at higher risk of being affected by endectocide use than is expected for other species of birds. To assess the risk that doramectin might indirectly affect burrowing owls by reducing their food supply, two separate studies were performed to address the following questions: 1) How toxic are residues of doramectin to insects breeding in dung of treated cattle? A result showing high levels of insecticidal activity would provide the basis for concerns that doramectin residues might affect burrowing owls. 2) What portion of the burrowing owl's diet is comprised of dung-breeding insects? If burrowing owls have a high level of reliance on dung insects, and if residues have high insecticidal activity, then use of doramectin on pastured cattle could have serious consequences for this endangered species.

\section{METHODS}

\section{Toxicity of Fecal Residues}

To test the insecticidal activity of doramectin residues in dung, we performed three experiments $(2003,2004,2005)$ at the Lethbridge Research Centre, Lethbridge, Alberta, Canada, using methods validated in previous similar studies (Floate 1998, Floate et al. 2002). In brief, cattle were housed in partially covered pens $(30 \times 50 \mathrm{~m}$ per pen), watered ad libitum, and maintained on a diet of barley silage, rolled barley, and distillers' grain supplement. Cattle were treated with doramectin in a topical formulation at the recommended dose of $500 \mu \mathrm{g} \cdot \mathrm{kg}^{-1}$ body weight (BW). Cattle were cared for in accordance with the guidelines of the Canadian Council for Animal Care and with the approval of the Lethbridge Research Centre Animal Care Committee (Protocols 0305, 0430, 0431).

In 2003, we collected dung on 17-18 February from the floor of a pen housing 10 untreated steers (335 kg mean BW). We used this dung as the control (i.e., Week 0). We then treated the cattle on 24 February and collected dung from the pen $4 \mathrm{wk}$, $8 \mathrm{wk}, 12 \mathrm{wk}$, and $14 \mathrm{wk}$ postapplication. Dung was collected fresh $(<3 \mathrm{~h}$ old $)$, from multiple pats, thoroughly mixed, and then held at $-20^{\circ} \mathrm{C}$ until needed. Our previous research documented reduced emergence of insects from dung of cattle treated 12 wk previously with ivermectin (Floate 1998). As a precaution, therefore, we used cattle that had not been previously treated with parasiticides for at least $16 \mathrm{wk}$ prior to the initiation of this experiment.

On 12 June, we formed dung pats of a standard volume $(0.5 \mathrm{~L})$ and shape using a plastic mold. Each pat was deposited on a $1-\mathrm{cm}$ layer of sand in a Styrofoam plate $(23 \mathrm{~cm}$ diameter). We placed the plates outdoors in an unshaded, level paddock adjacent to a pasture with cattle. There were 25 replicate pats per treatment (Weeks $0,4,8,12$, and $14 ; n=125$ total pats), with pat placement randomized in a $5 \times 5 \mathrm{~m}$ grid of five rows. Pats were protected from birds and rodents by chicken wire exclosures.

After exposure in the field to allow for insect colonization and oviposition, we collected the pats on 19 June and held them in insect emergence cages as per Floate (1998). We recovered the adult insects emerging in these cages during the next 3 mo and stored them in $70 \%$ ethanol for future sorting, counting, and species-level identification.

In 2004, we used the same methods as in 2003, but with the following deviations. We collected Week 0 dung on 14-15 
January from a pen housing 10 steers (338 kg mean BW). We treated the cattle on 16 January and collected dung $4 \mathrm{wk}$, $8 \mathrm{wk}, 12 \mathrm{wk}$, and $16 \mathrm{wk}$ postapplication. We initially exposed a set of pats in the field from 17 May to 27 May. Emergence of insects from all treatments including Week 0 was very low and unsuited to assess residue toxicity. Hence, we exposed a second set of pats in the field from 17 June to 24 June with 16 replicate pats per treatment (Weeks $0,4,8,12$, and 16; $n=80$ total pats). In addition, the cattle we used in 2004 had been treated with doramectin $12 \mathrm{wk}$ prior to use in the current study. We recognized that residues from this earlier treatment might be present in Week 0 dung, but no other cattle were available.

In 2005, we used the same methods as in 2003 and 2004, but with the following deviations. We collected Week 0 dung on 27 January from two pens housing 10 heifers ( $305 \mathrm{~kg}$ mean BW). We treated the cattle on 28 January and then collected dung $4 \mathrm{wk}, 8 \mathrm{wk}, 12 \mathrm{wk}$, and $16 \mathrm{wk}$ postapplication. We initially exposed a set of pats in the field from 27 May to 3 June on pasture $4 \mathrm{~km}$ west of Lethbridge. However, there was very low emergence of insects from these pats, which we attributed to heavy rains $(\mathrm{ca} .3-5 \mathrm{~cm}$ ) on 1-3 June. Hence, we exposed a second set of pats at the same site from 22 June to 28 June with 17 replicate pats per treatment (Weeks $0,4,8,12$, and 16; $n=85$ total pats). Similar to 2003 , parasiticides were not applied to cattle used in 2005 for a period of at least $16 \mathrm{wk}$ prior to collection of Week 0 dung.

Prior to statistical analyses, we excluded insects from the dataset if they had not developed in the experimental pats. Such insects were present as adults in emergence cages before they could have completed egg-adult development (e.g., see Floate 1998, fig. 1). We also excluded taxa that were not represented by at least 50 specimens in the dataset. We then performed an analysis of variance for each of the remaining species using insect count as the dependent variable with treatment (week of dung collection) as the independent variable. When a significant difference was detected, we performed a sequence of Dunnett's tests $\left(q_{0.05(1), \infty, p}\right)$ to test for differences between Week 0 and Week 4, then between Week 0 and Week 8, then between Week 0 and Week 12, and finally between Week 0 and Week 14 (in 2003) or Week 16 (in 2004 and 2005). When a difference was not detected, the remaining tests in the sequence were not performed. Thus, we attributed reduced insect emergence to doramectin residues only if an effect was first detected for dung with higher concentrations of residue. Because data were heteroscedastic among treatments, we rank-transformed the data prior to analyses (Conover and Iman 1984).

Throughout the paper, we report values as the mean \pm SE of untransformed data. We performed all statistical analyses using SYSTAT version 11 (SYSTAT, Richmond, CA).

\section{Diet Analyses}

To estimate the reliance of burrowing owls on dung-breeding insects, we collected regurgitated pellets from mid-April to late July 2004 at burrowing owl nest sites throughout the burrowing owl's range in southern Alberta and Saskatchewan (Fig. 1; Alberta Research Permit 15381, T.I.W.). The region is a largely treeless expanse in Canada's dry mixed-grass

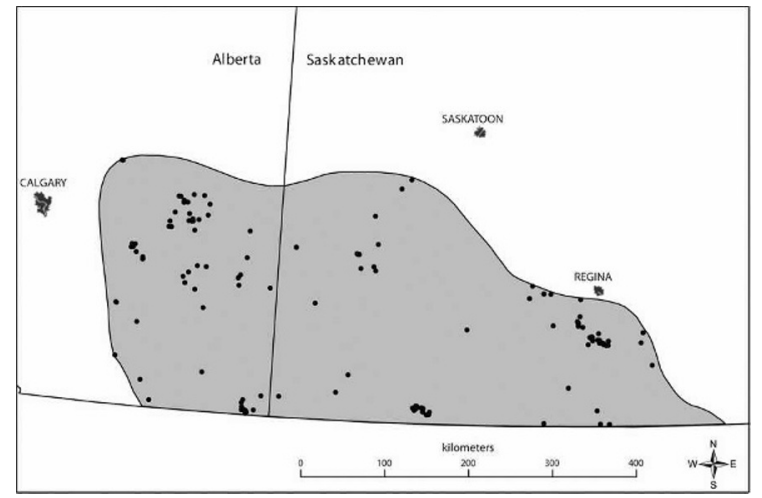

Figure 1. Geographic distribution of burrowing owl nests $(n=206)$ in southern Alberta and Saskatchewan, Canada, from which pellet samples were collected to determine the diet of burrowing owls for this study.

ecoregion. The ecoregion has a mean summer (May through August) temperature of $16^{\circ} \mathrm{C}$, a mean winter (November through February) temperature of $-10^{\circ} \mathrm{C}$, and a mean annual precipitation of 250-350 mm (Environment Canada 2008). Nest sites typically were located in fields of native or nonnative grassland grazed by cattle, in landscapes that varied from predominantly ranchland to predominantly cropland (grains, canola, flax, legumes). Sites were visited weekly or every second week during this period. We later soaked the pellets in a $\mathrm{NaOH}$ solution $(10 \%)$ for $1-3 \mathrm{~h}$ to dissolve the hair that tended to bind the contents of pellets together. We then washed the pellets through a $500-\mu \mathrm{m}$ sieve and dried the contents overnight in a drying oven. Using skulls, bones, feathers, and insect fragments, we subsequently counted and identified all prey items recovered from pellets.

In a companion study (Poulin and Todd 2006), we used infrared cameras to identify food items returned to the nest by foraging burrowing owls. Insect prey items were mainly beetles, grasshoppers and crickets (Orthoptera), and moths (Lepidoptera). Of these three groups, only beetles include dung-breeding species, primarily in the superfamily Scarabaeoidea within the families Geotrupidae (some species of Geotrupinae) and Scarabaeidae (some species of Scarabaeinae and Aphodiinae). To identify dung-breeding species, we classified beetles to family using head capsules from pellets with reference to specimens in the Canadian National Collection of Insects (Ottawa, Ontario, Canada). The head capsules of beetles in families Geotrupidae and Scarabaeidae then were examined in more detail to determine genus and species. Grasshoppers and crickets were identified using mandibles. Fragments of softerbodied insects (e.g., Diptera, Heteroptera, Hymenoptera, Lepidoptera) were rarely recovered from pellets. We identified mammals using skulls, for which we almost always were able to obtain species-level identifications. We also used skulls to identify birds, but did not attempt to identify species. Crayfish, lizards, and snakes were identified from a combination of bones, scales, and body fragments.

A biomass value was obtained for each taxon by multiplying the number of prey items by an estimated mean weight (Appendix I). We estimated the mean weight of dung beetles with measurements on each of 10 specimens for several species. 
Table 1. 2003. Average insect emergence per pat (mean \pm SE), from dung of untreated cattle (Week 0 ) vs. dung of cattle treated up to 14 wk previously with a recommended topical application of doramectin.

\begin{tabular}{|c|c|c|c|c|c|c|c|c|}
\hline Species & Week 0 & Week 4 & Week 8 & Week 12 & Week 14 & F ratio $\left(\mathrm{df}={ }_{4,120}\right)$ & $P$ value & Period of reduction ${ }^{1}$ \\
\hline \multicolumn{9}{|l|}{ Coleoptera (beetles) } \\
\hline Aleochara 'A' & $96.2 \pm 9.7$ & $21.6 \pm 4.5$ & $47.4 \pm 7.9$ & $54.8 \pm 5.8$ & $26.0 \pm 3.9$ & 18.894 & $<0.001$ & $>14$ wk \\
\hline Aleochara 'C' & $8.4 \pm 1.3$ & $9.0 \pm 1.1$ & $3.1 \pm 0.9$ & $3.9 \pm 0.8$ & $3.5 \pm 1.0$ & 10.433 & $<0.001$ & None detected \\
\hline Aleochara 'D' & $2.6 \pm 1.2$ & $1.3 \pm 0.3$ & $1.2 \pm 0.4$ & $1.1 \pm 0.3$ & $2.3 \pm 0.7$ & 0.588 & 0.672 & None detected \\
\hline Anthicidae & $2.9 \pm 1.2$ & $2.9 \pm 0.4$ & $2.2 \pm 0.5$ & $1.6 \pm 0.3$ & $0.6 \pm 0.2$ & 6.250 & $<0.001$ & None detected \\
\hline \multicolumn{9}{|l|}{ Aphodius vittatus } \\
\hline Say & $5.4 \pm 1.5$ & $7.2 \pm 2.5$ & $13.3 \pm 3.1$ & $8.6 \pm 1.8$ & $5.2 \pm 1.3$ & 2.097 & 0.085 & None detected \\
\hline \multicolumn{9}{|l|}{ Cercyon } \\
\hline quisquillius & $2.9 \pm 1.2$ & $1.4 \pm 0.2$ & $2.0 \pm 0.8$ & $5.6 \pm 1.3$ & $4.5 \pm 3.5$ & 1.291 & 0.277 & None detected \\
\hline Lathridiidae & $0.0 \pm 0.0$ & $1.4 \pm 0.9$ & $0.2 \pm 0.1$ & $0.04 \pm 0.04$ & $1.0 \pm 0.9$ & 1.349 & 0.256 & None detected \\
\hline \multicolumn{6}{|l|}{ Platystethus } & \multicolumn{3}{|c|}{ americanus } \\
\hline Erichson & $70.8 \pm 9.0$ & $43.8 \pm 6.1$ & $39.9 \pm 6.9$ & $42.5 \pm 6.0$ & $34.2 \pm 4.1$ & 4.088 & 0.004 & $>14 w k$ \\
\hline \multicolumn{9}{|l|}{ Diptera (flies) } \\
\hline Adia sp. & $3.6 \pm 0.5$ & $0.7 \pm 0.3$ & $1.6 \pm 0.9$ & $2.9 \pm 0.8$ & $2.0 \pm 0.7$ & 6.685 & $<0.001$ & $>14$ wk \\
\hline Calliphoridae & $0.8 \pm 0.4$ & $0.0 \pm 0.0$ & $0.2 \pm 0.2$ & $1.0 \pm 0.5$ & $0.4 \pm 0.2$ & 2.506 & 0.046 & None detected \\
\hline \multicolumn{9}{|l|}{ Coproica mitchelli } \\
\hline Malloch & $2.7 \pm 0.6$ & $0.3 \pm 0.2$ & $0.4 \pm 0.2$ & $3.0 \pm 0.6$ & $1.9 \pm 0.4$ & 13.411 & $<0.001$ & $>8 w k ;<12 w k$ \\
\hline \multicolumn{9}{|l|}{ Ischiolepta } \\
\hline micropyga Duda & $5.2 \pm 1.2$ & $1.6 \pm 0.5$ & $1.8 \pm 0.6$ & $3.0 \pm 0.7$ & $1.8 \pm 0.7$ & 4.827 & 0.001 & $>8 w k ;<12 w k$ \\
\hline Psychodidae & $0.2 \pm 0.1$ & $0.2 \pm 0.1$ & $0.4 \pm 0.2$ & $1.7 \pm 0.8$ & $1.1 \pm 0.4$ & 1.860 & 0.122 & None detected \\
\hline Sepsis sp. & $305.6 \pm 28.7$ & $0.3 \pm 0.1$ & $0.6 \pm 0.3$ & $33.0 \pm 6.3$ & $28.0 \pm 10.7$ & 94.246 & $<0.001$ & $>14$ wk \\
\hline \multicolumn{9}{|l|}{ Hymenoptera (wasps) } \\
\hline Species 'A' & $7.4 \pm 1.6$ & $0.3 \pm 0.1$ & $0.5 \pm 0.2$ & $6.4 \pm 0.8$ & $4.7 \pm 1.4$ & 30.55 & $<0.001$ & $>8 w k ;<12 w k$ \\
\hline Species 'C' & $1.8 \pm 0.5$ & $0.0 \pm 0.0$ & $0.1 \pm 0.1$ & $1.5 \pm 0.6$ & $0.2 \pm 0.1$ & 7.019 & $<0.001$ & $>8 w k ;<12 w k$ \\
\hline Species 'F' & $20.2 \pm 2.9$ & $0.5 \pm 0.3$ & $1.4 \pm 0.3$ & $9.9 \pm 1.9$ & $11.9 \pm 2.4$ & 33.828 & $<0.001$ & $>14$ wk \\
\hline \multicolumn{9}{|l|}{ Total for all } \\
\hline species & $571.2 \pm 39.5$ & $128.7 \pm 10.9$ & $136.2 \pm 14.3$ & $199.0 \pm 17.3$ & $139.6 \pm 16.2$ & 32.518 & $<0.001$ & $>14$ wk \\
\hline
\end{tabular}

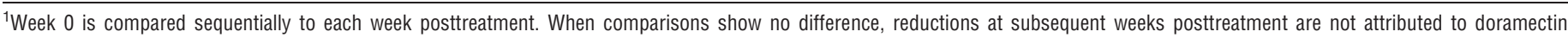
residues.

\section{RESULTS}

\section{Toxicity of Fecal Residues}

Results were consistent among years and showed residues of doramectin to have a high level of insecticidal activity in dung of cattle treated weeks to months previously. In 2003, the 29377 insects recovered from cages comprised at least 57 species. The 17 species retained for analyses represented $89.0 \%$ of the collection. Treatment effects attributed to doramectin residues were detected for nine species (Table 1). Emergence of four species was reduced in dung of cattle treated $\leq 8 \mathrm{wk}$ previously. Emergence of five species was reduced in dung of cattle treated $\leq 14$ wk previously.

In 2004, the 9147 insects recovered from cages comprised at least 33 species. The 14 species retained for analyses represented $94.5 \%$ of the collection. Treatment effects attributed to doramectin were detected for six species (Table 2). Emergence of two species was reduced in dung of cattle treated $\leq 4$ wk previously. Emergence of four species was reduced in dung of cattle treated $\leq 8$ wk previously.

In 2005, the 9767 insects recovered from cages comprised at least 12 species. The ten species retained for analyses represented $99.8 \%$ of the collection. Treatment effects attributed to doramectin were detected for four species (Table 3). Emergence of three species was reduced in dung of cattle treated $\leq 12 \mathrm{wk}$ previously. Emergence of one species was reduced in dung of cattle treated $\leq 16 \mathrm{wk}$ previously.

\section{Diet Analyses}

A total of 661 pellet samples were obtained from 206 burrowing owl nests (Fig. 1). A pellet sample comprised from 1 to about 50 pellets, collected from one nest on one date. Approximately 3\%, 36\%, 41\%, and 20\% of the samples were collected in April, May, June, and July, respectively. We identified a total of 50213 prey items (Table 4), of which $90 \%$ were invertebrates. Beetles (Coleoptera) comprised $54 \%$ of the total prey items, followed next in abundance by grasshoppers (Acrididae, 20\%) and crickets (Gryllidae, 16\%). Beetles were primarily ground beetles (Carabidae). Less abundant, but still common, taxa included carrion beetles (Silphidae), darkling beetles (Tenebrionidae), and Scarabaeoidea. Fourteen taxa of Scarabaeoidea ( $n=1723$ specimens) were identified, of which seven taxa ( $n=1381$ specimens) included species of dungbreeding beetles (Scarabaeinae, Aphodiinae; Table 5). Other 
Table 2. 2004. Average insect emergence per pat (mean \pm SE), from dung of untreated cattle (Week 0 ) vs. dung of cattle treated up to 16 wk previously with a recommended topical application of doramectin.

\begin{tabular}{|c|c|c|c|c|c|c|c|c|}
\hline Species & Week 0 & Week 4 & Week 8 & Week 12 & Week 16 & F ratio $\left(\mathrm{df}={ }_{4,74}\right)$ & $P$ value & Period of reduction ${ }^{1}$ \\
\hline \multicolumn{9}{|l|}{ Coleoptera (beetles) } \\
\hline Aleochara 'A' & $4.3 \pm 1.1$ & $0.8 \pm 0.5$ & $3.5 \pm 1.4$ & $3.6 \pm 1.1$ & $2.9 \pm 0.9$ & 2.84 & 0.030 & $>4$ wk; $<8$ wk \\
\hline Aleochara 'D' & $5.9 \pm 1.9$ & $0.7 \pm 0.3$ & $0.5 \pm 0.2$ & $6.8 \pm 1.8$ & $1.6 \pm 0.4$ & 10.687 & $<0.001$ & $>8 w k ;<12 w k$ \\
\hline \multicolumn{9}{|l|}{ Aphodius } \\
\hline granarius L. & $3.1 \pm 1.2$ & $0.4 \pm 0.2$ & $1.7 \pm 1.1$ & $0.1 \pm 0.1$ & $0.8 \pm 0.5$ & 2.554 & 0.046 & None detected \\
\hline Philonthus 'A' & $1.3 \pm 0.4$ & $0.9 \pm 0.3$ & $1.1 \pm 0.3$ & $0.4 \pm 0.2$ & $0.7 \pm 0.3$ & 0.847 & 0.500 & None detected \\
\hline \multicolumn{9}{|l|}{ Diptera (flies) } \\
\hline Adia sp. & $18.9 \pm 9.2$ & $0.2 \pm 0.1$ & $5.4 \pm 4.4$ & $86.0 \pm 22.1$ & $5.4 \pm 1.7$ & 20.617 & $<0.001$ & $>4 w k ;<8 w k$ \\
\hline Chironomidae & $1.2 \pm 0.6$ & $0.3 \pm 0.3$ & $0.8 \pm 0.6$ & $1.1 \pm 0.5$ & $1.8 \pm 1.1$ & 0.594 & 0.668 & None detected \\
\hline \multicolumn{9}{|l|}{ Coproica mitchelli } \\
\hline micropyga Duda & $43.2 \pm 8.0$ & $2.2 \pm 0.4$ & $21.0 \pm 5.9$ & $46.3 \pm 8.4$ & $39.8 \pm 5.2$ & 18.997 & $<0.001$ & $>8 w k ;<12 w k$ \\
\hline Leptocera & $0.3 \pm 0.2$ & $0.1 \pm 0.1$ & $0.2 \pm 0.1$ & $1.2 \pm 0.6$ & $5.8 \pm 2.1$ & 3.829 & 0.007 & None detected \\
\hline Sepsis sp. & $0.1 \pm 0.1$ & $0.2 \pm 0.1$ & $0.3 \pm 0.2$ & $4.0 \pm 2.3$ & $93.8 \pm 13.2$ & 40.854 & $<0.001$ & None detected \\
\hline \multicolumn{9}{|l|}{ Hymenoptera (wasps) } \\
\hline Species 'F' & $2.9 \pm 1.0$ & $0.0 \pm 0.0$ & $0.1 \pm 0.1$ & $35.4 \pm 8.6$ & $5.8 \pm 1.7$ & 43.201 & $<0.001$ & $>8 w k ;<12$ wk \\
\hline \multicolumn{9}{|l|}{ Total for species } \\
\hline above & $107.1 \pm 16.1$ & $12.3 \pm 1.7$ & $47.0 \pm 10.2$ & $214.1 \pm 30.7$ & $191.2 \pm 16.7$ & 24.332 & $<0.001$ & $>8 w k ;<12 w k$ \\
\hline
\end{tabular}

${ }^{1}$ Week 0 is compared sequentially to each week posttreatment. When comparisons show no difference, reductions at subsequent weeks posttreatment are not attributed to doramectin residues.

families of beetles recovered included click beetles (Elateridae), weevils (Curculionidae), rove beetles (Staphylinidae), and hister beetles (Histeridae). A complete list of beetle taxa is provided in Table 5. The most numerically abundant vertebrate taxa, in descending order, were deer mice (Peromyscus maniculatus Wagner), sagebrush voles (Lemmiscus curtatus Cope), meadow voles (Microtus pennsylvanicus Ord), and unidentified passerines (Table 4).

Table 3. 2005. Average insect emergence per pat (mean \pm SE), from dung of untreated cattle (Week 0) vs. dung of cattle treated up to 16 wk previously with a recommended topical application of doramectin.

\begin{tabular}{|c|c|c|c|c|c|c|c|c|}
\hline Species & Week 0 & Week 4 & Week 8 & Week 12 & Week 16 & F ratio $\left(\mathrm{df}={ }_{4,74}\right)$ & $P$ value & Period of reduction ${ }^{1}$ \\
\hline \multicolumn{9}{|c|}{ Coleoptera (beetles) } \\
\hline Aleochara 'A' & $57.0 \pm 5.6$ & $33.1 \pm 3.7$ & $30.7 \pm 4.3$ & $37.6 \pm 5.5$ & $44.8 \pm 8.9$ & 4.095 & 0.005 & $>12 w k ;<16 w k$ \\
\hline Aleochara 'C' & $7.5 \pm 1.8$ & $12.3 \pm 2.8$ & $14.5 \pm 2.2$ & $10.8 \pm 1.8$ & $10.4 \pm 2.4$ & 1.670 & 0.165 & none detected \\
\hline Aleochara 'D' & $3.0 \pm 0.9$ & $3.4 \pm 0.6$ & $2.2 \pm 1.2$ & $2.6 \pm 0.9$ & $2.4 \pm 0.5$ & 1.882 & 0.122 & none detected \\
\hline \multicolumn{9}{|l|}{ Diptera (flies) } \\
\hline Adia sp. & $0.2 \pm 0.2$ & $0.0 \pm 0.0$ & $2.2 \pm 1.5$ & $1.0 \pm 0.6$ & $0.3 \pm 0.2$ & 1.178 & 0.327 & none detected \\
\hline \multicolumn{9}{|c|}{ Coproica mitchelli } \\
\hline Malloch & $87.1 \pm 11.5$ & $0.2 \pm 0.1$ & $1.2 \pm 0.5$ & $27.4 \pm 4.9$ & $65.8 \pm 9.6$ & 91.302 & $<0.001$ & $>12 w k ;<16$ wk \\
\hline Forcipomyiinae & $0.4 \pm 0.3$ & $0.3 \pm 0.2$ & $2.8 \pm 2.8$ & $0.3 \pm 0.3$ & $0.3 \pm 0.1$ & 0.308 & 0.872 & none detected \\
\hline Ravinia spp. & $0.4 \pm 0.3$ & $0.3 \pm 0.2$ & $2.0 \pm 0.6$ & $1.3 \pm 0.5$ & $2.4 \pm 0.8$ & 4.175 & 0.004 & none detected \\
\hline Sepsis sp. & $51.7 \pm 11.8$ & $0.2 \pm 0.1$ & $0.1 \pm 0.1$ & $3.6 \pm 1.9$ & $36.9 \pm 11.1$ & 37.818 & $<0.001$ & $>12 w k ;<16$ wk \\
\hline \multicolumn{9}{|c|}{ Hymenoptera (wasps) } \\
\hline Species 'D’ & $2.6 \pm 1.9$ & $0.9 \pm 0.9$ & $0.0 \pm 0.0$ & $0.0 \pm 0.0$ & $1.0 \pm 0.6$ & 3.133 & 0.019 & none detected \\
\hline Species 'F' & $10.8 \pm 2.4$ & $0.1 \pm 0.1$ & $0.5 \pm 0.3$ & $0.7 \pm 0.4$ & $6.3 \pm 2.0$ & 24.521 & $<0.001$ & $>16$ wk \\
\hline \multicolumn{9}{|l|}{ Total for species } \\
\hline above & $220.8 \pm 22.8$ & $50.7 \pm 4.5$ & $56.2 \pm 7.2$ & $85.2 \pm 10.2$ & $170.7 \pm 19.4$ & 31.947 & $<0.001$ & $>12 w k ;<16 w k$ \\
\hline
\end{tabular}

${ }^{1}$ Week 0 is compared sequentially to each week posttreatment. When comparisons show no difference, reductions at subsequent weeks posttreatment are not attributed to doramectin residues. 
Table 4. Prey items recovered from burrowing owl pellets.

\begin{tabular}{|c|c|c|c|c|}
\hline Taxa & No. & $\begin{array}{c}\text { Biomass } \\
\text { (g) }\end{array}$ & $\begin{array}{c}\text { No. } \\
\text { (\% of total) }\end{array}$ & $\begin{array}{l}\text { Biomass } \\
\text { (\% of total) }\end{array}$ \\
\hline \multicolumn{5}{|l|}{ Vertebrates } \\
\hline Peromyscus maniculatus & 2290 & 44800 & 4.56 & 36.51 \\
\hline Microtus pennsylvanicus & 695 & 19182 & 1.38 & 15.63 \\
\hline Lemmiscus curtatus & 1139 & 23577 & 2.27 & 19.22 \\
\hline Onychomys leucogaster & 65 & 1872 & 0.13 & 1.53 \\
\hline Mus musculus & 30 & 549 & 0.06 & 0.45 \\
\hline Perognathus fasciatus & 115 & 1127 & 0.23 & 0.92 \\
\hline Sorex haydeni & 143 & 343 & 0.29 & 0.28 \\
\hline Sorex obscurus & 3 & 16 & 0.01 & 0.01 \\
\hline Blarina brevicauda & 1 & 22 & $<0.01$ & 0.02 \\
\hline Spermophilus richardsonii & 20 & 1520 & 0.04 & 1.24 \\
\hline Lepus sp. & 12 & 1080 & 0.02 & 0.88 \\
\hline Thomomys talpoides & 23 & 1495 & 0.05 & 1.22 \\
\hline Dipdomys ordii & 6 & 358 & 0.01 & 0.29 \\
\hline Zapus sp. & 3 & 73 & 0.01 & 0.06 \\
\hline \multicolumn{5}{|l|}{ Spermophilus } \\
\hline tridecemlineatus & 2 & 144 & $<0.01$ & 0.12 \\
\hline Passerines & 290 & 7975 & 0.58 & 6.50 \\
\hline Anurans & 91 & 1365 & 0.18 & 1.11 \\
\hline Ambystoma tigrinum & 35 & 539 & 0.07 & 0.44 \\
\hline Thamnophis sp. & 5 & 251 & 0.01 & 0.20 \\
\hline \multicolumn{5}{|l|}{ Phrynosoma } \\
\hline hernandesi & 1 & 10 & $<0.01$ & 0.01 \\
\hline Unidentified Cricetidae & 50 & 1100 & 0.10 & 0.90 \\
\hline Total vertebrates & 5019 & 107398 & 10.00 & 87.53 \\
\hline \multicolumn{5}{|l|}{ Invertebrates } \\
\hline Cambarus sp. & 2 & 13 & $>0.1$ & 0.01 \\
\hline Coleoptera (beetles) & $27207^{\star}$ & $6078^{1}$ & 54.18 & 4.95 \\
\hline Acrididae (grasshoppers) & 10066 & 6040 & 20.05 & 4.92 \\
\hline Gryllidae (crickets) & 7919 & 3168 & 15.77 & 2.58 \\
\hline Total invertebrates & 45194 & 15299 & 90.00 & 12.47 \\
\hline Total & 50213 & 122697 & 100.00 & 100.00 \\
\hline
\end{tabular}

${ }^{1}$ See Table 6

Based on recoveries from pellets, we estimated a mean weight of $0.10 \mathrm{~g}$ for Scarabaeoidea (Table 5). Canthon pilularius L. $(0.46 \mathrm{~g})$ was one of the largest species, but comprised only $5 \%$ of the 1723 specimens recovered (Table 6). Mean weights for other species common in pellets were Aphodius fossor (0.09 g), Onthophagus nuchicornis L. (0.06 g), Aphodius spp. (= Aphodius erraticus L. and Aphodius fimetarius L. [0.03 g], Aphodius prodromus Brahm [0.02 g], and Aphodius granarius L. [0.01 g]).

Prey items represented an estimated total biomass of $122697 \mathrm{~g}$ (Table 4). Deer mice were the largest contributor to this total $(36.5 \%)$, followed by sagebrush voles $(19.2 \%)$ and meadow voles $(15.6 \%)$. The numerically dominant invertebrates collectively represented only $12 \%$ of total prey biomass. Beetles, grasshoppers, and crickets comprised $5.0 \%, 4.9 \%$, and $2.6 \%$ of the total prey biomass. Using an average weight of $0.1 \mathrm{~g}$ per beetle, the total number of dung-breeding beetles recovered from pellets comprised an estimated $2.8 \%$ of the total prey items or $0.1 \%$ of total prey biomass.

\section{DISCUSSION}

Results of the 3-yr toxicity study provide the largest single dataset thus far to assess the insecticidal activity of doramectin residues in dung of treated animals (Tables 1-3). Findings were in agreement across years and showed residues to reduce the numbers of insects developing in dung of cattle treated weeks to months previously. Further, these data extend by 1-2 mo the known posttreatment period for which residues are excreted in feces at levels sufficient to suppress populations of at least some insect species. Horn fly, Haematobia irritans L.; house fly, Musca domestica L.; and stable fly, Stomoxys calcitrans L. (Diptera: Muscidae) previously were shown to be reduced in dung from cattle topically dosed with doramectin for at least 4 wk post-treatment (Floate et al. 2001). The same observation was reported in a subsequent study for a further eight taxa, including dung-feeding flies, predaceous beetles, and parasitoid wasps (Floate et al. 2002). Larvae of the flies Musca inferior Stein and Orthelia timeroensis Robineau-Desvoidy (Muscidae) were suppressed in dung voided for a period of $9 \mathrm{~d}$ to $15 \mathrm{~d}$ following subcutaneous (SC) injection of doramectin into cattle (Wardhaugh et al. 2001). Following similar treatment, larvae of the fly Sarcopromusca pruna Shannon \& Del Pont (Muscidae) were suppressed in dung from cattle voided at least 36 d postapplication (Silva Junior 1997, cited in Steel and Wardhaugh 2002). Reduced numbers of arthropods also have been reported in dung from cattle treated 3 wk previously with a SC dose of doramectin (Suarez et al. 2008). In the current study, there were two cases of taxa being affected for at least $4 \mathrm{wk}$, nine cases of taxa affected for at least $8 \mathrm{wk}$, four cases of taxa affected for at least $12 \mathrm{wk}$, six cases of taxa being affected for at least $14 \mathrm{wk}$, and one case of a taxon being affected for at least 16 wk (Tables 1-3). We did not test for effects beyond $16 \mathrm{wk}$.

The toxicity of these residues to at least some species was exemplified in 2004, when Sepsis flies were essentially absent in control pats and no effect of treatment was detected for this species (Table 2). In contrast, emergence of Sepsis from Week 4 dung was suppressed 1018-fold in 2003 (Table 1), and 258fold in 2005 (Table 3), relative to control pats. Further, a treatment effect was detected in dung from cattle $\leq 14 \mathrm{wk}$ (2003) and $\leq 12 \mathrm{wk}$ (2005) after application of doramectin. We attribute the low emergence of Sepsis in 2004 to a treatment of doramectin applied to cattle $12 \mathrm{wk}$ prior to their use in the current study. Although we were aware that this preexperimental treatment might introduce low levels of residue to control pats, we did not anticipate the observed high level of toxicity. This finding illustrates the importance of using livestock with a known treatment history extending back for at least 4 mo. If we did not have such information for our 2004 study, and if we had not repeated the study in different years, we would have underestimated the insecticidal activity of doramectin residues.

The current study provided little information on the toxicity of doramectin residues to dung beetles (Scarabaeidae). Dung beetles were active during the time that experimental pats were exposed in the field (Floate and Gill 1998). However, only Aphodius granarius and Aphodius vittatus Say were recovered from emergence cages in sufficient numbers for statistical analyses. Results for these species showed no effect of residues 
Table 5. Beetles recovered from burrowing owl pellets.

\begin{tabular}{|c|c|c|c|c|c|}
\hline Taxon & No. & Individual weight (g) & Taxon biomass $(\mathrm{g})$ & Taxon no. (\% of total) & Taxon biomass ( $\%$ of total) \\
\hline Carabidae & 20785 & 0.2 & 4157.0 & 76.40 & 68.39 \\
\hline Silphidae & 2369 & 0.3 & 710.7 & 8.71 & 11.69 \\
\hline Scarabaeoidea $^{1}$ & 1723 & 0.1 & 172.3 & 6.33 & 2.83 \\
\hline Tenebrionidae & 1489 & 0.6 & 893.4 & 5.47 & 14.70 \\
\hline Curculionidae & 232 & 0.1 & 23.2 & 0.85 & 0.38 \\
\hline Elateridae & 208 & 0.2 & 41.6 & 0.77 & 0.68 \\
\hline Staphylinidae & 156 & 0.2 & 31.2 & 0.57 & 0.51 \\
\hline Histeridae & 133 & 0.2 & 26.6 & 0.49 & 0.44 \\
\hline Dytiscidae & 42 & 0.2 & 8.4 & 0.15 & 0.14 \\
\hline Chrysomelidae & 42 & 0.2 & 8.4 & 0.15 & 0.14 \\
\hline Dermestidae & 15 & 0.2 & 3 & 0.06 & 0.05 \\
\hline Hydrophilidae & 4 & 0.2 & 0.8 & 0.02 & 0.01 \\
\hline Meloidae & 3 & 0.2 & 0.6 & 0.01 & 0.01 \\
\hline Cerambycidae & 3 & 0.2 & 0.6 & 0.01 & 0.01 \\
\hline Melyridae & 1 & 0.2 & 0.2 & $<0.01$ & $<0.01$ \\
\hline Coccinellidae & 1 & 0.2 & 0.2 & $<0.01$ & $<0.01$ \\
\hline Total & 27207 & & 6078.2 & 100.00 & 100.00 \\
\hline
\end{tabular}

${ }^{1}$ Families in superfamily Scarabaeoidea are listed in Table 6.

in Week 4 dung, which contained the highest concentration of residues (Tables 1 and 2). This finding agrees with previous studies and indicates that dung beetles are less affected by endectocide residues than are many other dung-breeding taxa (e.g., Coleoptera: Staphylinidae [Aleochara sp.], Diptera, Hymenoptera; see Tables 1-3). Using the same method and study site, A. granarius was suppressed in dung of cattle treated topically with ivermectin $1 \mathrm{wk}$ and 2 wk previously, but not in dung of cattle treated similarly with doramectin, eprinomectin, or moxidectin (Floate et al. 2002). No suppression by any of the four endectocides was detected for A. vittatus in the same study (Floate et al. 2002). Aphodius fimetarius and A. vittatus, respectively, were suppressed in dung of cattle treated $1 \mathrm{wk}$ and $3 \mathrm{wk}$, but not $4 \mathrm{wk}$, previously with ivermectin in a topical application (Floate 1998). Collectively, these results indicate that topical formulations of endectocides (including doramectin) are unlikely to suppress numbers of dung beetles developing in dung deposited beyond $3 \mathrm{wk}$ postapplication. With one exception (Dadour et al. 2000; i.e., effects of abamectin on Onthophagus binodis Thunberg), this conclusion is supported with results of laboratory bioassays on individual species of dung beetles reared in dung of cattle treated with SC or topical applications of endectocides (summarized in Steel and Wardhaugh 2002, table 4.1). It is recognized, however, that different species of insects have different levels of susceptibility and that residues may cause sublethal effects that affect insect reproduction (reviewed in Floate et al. 2005). Hence, this apparently general pattern for dung beetles may have exceptions not yet reported.

Diet analyses identified burrowing owls as generalist predators feeding on a large assortment of vertebrate and invertebrate prey. Prey identified in the current study included mice (P. maniculatus, Onychomys leucogaster Wied-Neuwied, Mus musculus L., Perognathus fasciatus Wied-Neuwied, Zapus sp.), shrews (Blarina brevicauda Say, Sorex haydeni Baird, Sorex monticolus [obscurus] Merriam), voles (L. curtatus, M. pennsylvanicus), ground squirrels (Spermophilus spp.), northern pocket gopher (Thomomys talpoides Richardson), Ord's kangaroo rat (Dipodomys ordii Woodhouse), hares (Lepus sp.), passerines, amphibians (Ambystoma tigrinum Green, anurans), reptiles (Thamnophis sp., Phrynosoma hernandesi Girard), crayfish (Cambarus sp.), and numerous species of insects (primarily Orthoptera and Coleoptera). In a previous study in southern Alberta, the passerine prey of burrowing owls mainly included horned larks (Eremophila alpestris L.), secondarily included chestnut-collared longspurs (Calcarius ornatus J. K. Townsend), and then Baird's sparrow (Ammodramus bairdii Audubon) and savannah sparrow (Passerculus sandwichensis Gmelin) plus western meadowlark (Sturnella neglecta Audubon; Sissons 2003). Studies elsewhere have reported a similar breadth of prey in the diet of burrowing owls (Longhurst 1942; Coulombe 1971; Marti 1974; Schlatter et al. 1980; Green and Anthony 1989; Sissons 2003).

The pattern of invertebrate consumption in the current study ( $90 \%$ of prey items, but only $10 \%$ of prey biomass) compares well to previous reports and identifies dung-breeding insects as only a small portion of burrowing owl diets. Invertebrates were $20 \%$ of prey biomass in north-central Oregon (Green and Anthony 1989), and were $12 \%$ to $20 \%$ of prey biomass in southern Alberta (Sissons 2003). Species in the latter study mainly were represented by carrion beetles, darkling beetles, ground beetles, grasshoppers, and camel crickets (Rhaphidophoridae; Sissons 2003). Insects were $6 \%$ to $14 \%$ of prey biomass in north-central Colorado, and predominantly were ground beetles, grasshoppers, crickets, carrion beetles, and scarab beetles (Marti 1974). Because the genera of scarab beetles were not identified in the latter study, they may or may not have included dung-breeding species. In an earlier study in Colorado, insects most commonly consumed by burrowing owls included grasshoppers, carrion beetles, darkling beetles, and scarab beetles in the genus Diplotaxis (Longhurst 1942). We also found considerable numbers of Diplotaxis (Table 6), 
Table 6. Species of Scarabaeoidea recovered from burrowing owl pellets. Species that breed in dung are identified with an asterisk $\left({ }^{\star}\right)$.

\begin{tabular}{|c|c|c|}
\hline Taxa & No. & No. ( $\%$ of total) \\
\hline \multicolumn{3}{|l|}{ Ochodaeidae } \\
\hline \multicolumn{3}{|l|}{ Ochodaeinae } \\
\hline Ochodaeus simplex LeConte & 9 & 0.52 \\
\hline \multicolumn{3}{|l|}{ Geotrupidae } \\
\hline \multicolumn{3}{|l|}{ Bolboceratinae } \\
\hline${ }^{\star}$ Eucanthus greeni Robinson & 5 & 0.29 \\
\hline \multicolumn{3}{|l|}{ Trogidae } \\
\hline Trox atrox LeConte & 49 & 2.84 \\
\hline Trox spp. & 75 & 4.35 \\
\hline \multicolumn{3}{|l|}{ Scarabaeidae } \\
\hline \multicolumn{3}{|l|}{ Scarabaeinae } \\
\hline \multicolumn{3}{|l|}{ Canthonini } \\
\hline${ }^{*}$ Canthon pilularius $\mathrm{L}$. & 90 & 5.22 \\
\hline${ }^{\star}$ Canthon praticola LeConte & 483 & 28.03 \\
\hline${ }^{\star}$ Canthon simplex LeConte & 28 & 1.63 \\
\hline \multicolumn{3}{|l|}{ Onthophagini } \\
\hline${ }^{\star}$ Onthophagus hecate Panzer & 3 & 0.17 \\
\hline *Onthophagus nuchicornis L. & 224 & 13.00 \\
\hline \multicolumn{3}{|l|}{ Aphodiinae } \\
\hline \multicolumn{3}{|l|}{ Aphodiini } \\
\hline${ }^{\star}$ Aphodius fossor $\mathrm{L}$. & 295 & 17.12 \\
\hline${ }^{\star}$ Aphodius spp. & 253 & 14.68 \\
\hline \multicolumn{3}{|l|}{ Melolonthinae } \\
\hline \multicolumn{3}{|l|}{ Sericini } \\
\hline Serica intermixta Blatchley & 1 & 0.06 \\
\hline Serica curvata LeContre (?) & 6 & 0.35 \\
\hline \multicolumn{3}{|l|}{ Diplotaxini } \\
\hline Diplotaxis brevicollis LeContre (?) & 120 & 6.97 \\
\hline \multicolumn{3}{|l|}{ Melolonthini } \\
\hline Phyllophaga spp. & 9 & 0.52 \\
\hline \multicolumn{3}{|l|}{ Macrodactylini } \\
\hline $\begin{array}{l}\text { Dichelonyx fulgida LeContre (?) or Dichelonyx } \\
\text { kirbyi Brown }\end{array}$ & 4 & 0.23 \\
\hline \multicolumn{3}{|l|}{ Dynastinae } \\
\hline \multicolumn{3}{|l|}{ Pentodontini } \\
\hline Tomarus relictus Say & 42 & 2.44 \\
\hline \multicolumn{3}{|l|}{ Cetoniinae } \\
\hline \multicolumn{3}{|l|}{ Cetoniini } \\
\hline Euphoria inda L. & 5 & 0.29 \\
\hline \multicolumn{3}{|l|}{ Cremastocheilini } \\
\hline Cremastocheilus knochii LeConte & 19 & 1.10 \\
\hline Damaged or unidentifiable & 3 & 0.17 \\
\hline Total & 1723 & 100.0 \\
\hline
\end{tabular}

but note that they do not breed in dung. Ground beetles and scarab beetles were common prey of burrowing owls in Chile, but genera were not identified (Schlatter et al. 1980). Jerusalem crickets (Stenopelmatus fuscus Haldeman) and unidentified Coleoptera were the most common insects identified as prey in Oakland, California (Thomsen 1971), whereas earwigs (Dermaptera) were common insect prey in the Imperial Valley, California (Coulombe 1971). Jerusalem crickets, grasshoppers, and carrion beetles were common insects consumed by burrowing owls in south-central Idaho (Rich 1986).

We considered the possibility that burrowing owls forage in dung for fly larvae and beetle grubs. Foraging in dung by other species of birds has been reported by others (Newstead 1908; Hammer 1941; Laurence 1954; Valiela 1969; Anderson and Merritt 1977). If so, the absence of fragments from these softbodied insects in pellets could underestimate their importance in the owl's diet. However, foraging activity by burrowing owls only has been reported to include direct flights from perches to capture prey in the air or on the ground, hovering activity, or chasing down prey on the ground (Coulombe 1971; Thomsen 1971; Marti 1974). Furthermore, we could find no signs of foraging activity in cattle dung pats $(n=2623)$ aged $7-10 \mathrm{~d}$ examined in southern Alberta pastures (K. D. Floate, unpublished data, 2003-2005). Because bird foraging typically results in the pat being scattered about in pieces (Hammer 1941; Laurence 1954; Valiela 1969; Anderson and Merritt 1977), such activity is unlikely to be overlooked. With regards to other species, Anderson and Merritt (1977) made $110 \mathrm{~h}$ of observations over $4 \mathrm{yr}$ to identify birds foraging in dung on pastures in northern California. Only western meadowlarks were observed to forage in dung, and experimental studies showed that they were foraging for seeds-not insects.

We are uncertain how to interpret the results of Levey et al. (2004) in the context of the current study. Burrowing owls commonly line their burrows with dry animal dung (Haug et al. 1993). The purpose of this behavior is unknown, but it may attract dung-breeding insects that are then consumed by the owls: i.e., the prey attraction hypothesis. Levey et al. (2004) showed the dung beetle, Phanaeus igneus Macleay, to comprise $65 \%$ of the beetles consumed by burrowing owls in Gilchrist County, Florida. Experimental studies subsequently showed increased captures of these beetles when cattle dung was placed at the entrance of burrowing owl nests (Levey et al. 2004). Indirect support for the prey attraction hypothesis comes from Smith and Conway (2007), who showed increased capture of arthropods in pitfall traps when manure was present in the immediate area. Collectively, these findings suggest that use of endectocides, by reducing numbers of dung beetles, could adversely affect burrowing owls. However, the level of reported $P$. igneus consumption is based on a small number of pellets $(n=20)$, which may not reflect the general pattern of dung beetle consumption. For numbers of the dung beetle, Onthophagus nuchicornis L., recovered in the current study, $56 \%$ of the 224 individuals came from one of the 661 pellet samples examined. Furthermore, results of Levey et al. (2004) provide no information on the contribution of dung beetles to total prey biomass during the season. Smith and Conway (2007) point out that burrowing owls commonly spread other materials, such as grass or fur tufts and bits of human trash in their burrow entrances and nesting chambers, a behavior also observed for owls in our study area (T. I. Wellicome and R. Poulin, personal observation). Smith and Conway acknowledge that there are several other, thus far untested, hypotheses that may explain manure nest-lining behavior by owls, for example insulation or water absorption functions. Interestingly, over a century ago, it was known that road-runners also invariably line their shrub nests with dried livestock manure (Grinnell 1983). Like burrowing owls, road-runners have large clutch sizes, and 
dried shredded manure might increase hatching and nesting success by increasing the incubation efficiency or limiting the negative effects of rain.

\section{IMPLICATIONS}

Our results show that fecal residues can reduce numbers of insects breeding in dung of cattle treated weeks to months previously with a recommended topical dose of doramectin. This finding was consistent in each of $3 \mathrm{yr}$ and provides initial justification for the concern that use of doramectin could adversely burrowing owls, which consume large numbers of insects. These insects include dung beetles such as species of Aphodius, Canthon, and Onthophagus as determined in the current study. However, results of the current and previous studies on burrowing owl diets show invertebrates to typically comprise less than $20 \%$ of total prey biomass during the nesting season, of which dung beetles comprise a much smaller fraction. Dung beetles comprised an estimated $0.1 \%$ of total prey biomass in the current study. In view of these collective observations, we conclude that use of doramectin to treat cattle on pastures does not pose a significant risk to co-occurring populations of burrowing owls.

\section{ACKNOWLEDGMENTS}

K.D.F. thanks D. Cheung, C. Pickett, A. Bevins, E. Campbell, A. Thorn, and particularly P. Coghlin for technical support to assess the effect of doramectin residues on dung-breeding insects. P.B thanks E. St.-Louis for sorting the beetle specimens and conducting the preliminary identifications and B. Gill (Canadian Food Inspection Agency, Ottawa, Ontario, Canada) for confirming identifications of Scarabaeoidea. T.I.W. thanks F. Blouin, A. Mitchell, S. Stevens, D. Shyry, and D. Todd for assisting with burrowing owl fieldwork. R.P. thanks T. Schowalter for processing vertebrate specimens from pellets and C. Cassidy-St. Clair (University of Alberta) for logistic support. We thank I. Walker and his staff for facilitating research on Onefour, Alberta, Canada. This is Lethbridge Research Centre Contribution 387-08020.

\section{LITERATURE CITED}

Anderson, J. R., and R. W. MerRitt. 1977. The impact of foraging meadowlarks, Sturnella neglecta, on the degradation of cattle dung pads. Journal of Applied Ecology 14:355-362.

BLumE, R. R. 1985. A check-list, distributional record, and annotated bibliography of the insects associated with bovine droppings on pasture in America north of Mexico. Southwestern Entomologist (Supplement) 9:1-55.

Bragg, A. N. 1940. Observations on the ecology and natural history of Anura. I. Habits, habitat and breeding of Bufo cognatus Say. The American Naturalist 74:424-438.

Committee on the Status of Endangered Wildlife in Canada. 2006. COSEWIC assessment and update status report on the burrowing owl Athene cunicularia in Canada. Ottawa, ON, Canada: Committee on the Status of Endangered Wildlife in Canada. 31 p. Available at: http://www.sararegistry.gc.ca/virtual_ sara/files/cosewic/sr\%5Fburrowing\%5Fowl $\% 5 \mathrm{Fe} \% 2$ Epdf. Accessed 1 April 2008.

Conover, W. J., And R. L. Iman. 1984. Rank transformations as a bridge between parametric and nonparametric statistics. The American Statistician $35: 124-129$.
Coulombe, H. N. 1971. Behavior and population ecology of the burrowing owl, Speotyto cunicularia, in the Imperial Valley of California. The Condor 73:162-176.

Dadour, I. R., D. F. Cook, and D. Hennessy. 2000. Reproduction and survival of the dung beetle Onthophagus binodis (Coleoptera: Scarabaeidae) exposed to abamectin and doramectin residues in cattle dung. Environmental Entomology 26:1116-1122.

Environment Canada. 2008. Narrative descriptions of terrestrial ecozones and ecoregions of Canada. Available at: http://www.ec.gc.ca/soer-ree/English/ Framework/Nardesc/praire_e.cfm. Accessed 1 April 2008.

FincheR, G. T. 1981. The potential value of dung beetles in pasture ecosystems. Journal of the Georgia Entomological Society 16:301-316.

FloATE, K. D. 1998. Off-target effects of ivermectin on insects and on dung degradation in southern Alberta, Canada. Bulletin of Entomological Research 88:25-35.

FLoATE, K. D. 2006. Endectocide use on cattle and faecal residues: an assessment of environmental effects in Canada. Canadian Journal of Veterinary Research 70:1-10

Floate, K. D., D. D. Colwell, and A. S. Fox. 2002. Reductions of non-pest insects in dung of cattle treated with endectocides: a comparison of four products. Bulletin of Entomological Research 92:471-481.

Floate, K. D., and B. D. Gill. 1998. Seasonal activity of dung beetles (Coleoptera: Scarabaeidae) associated with cattle dung in southern Alberta and their geographic distribution in Canada. Canadian Entomologist 130:131151.

Floate, K. D., R. W. Spooner, and D. D. Colwell. 2001. Larvicidal activity of endectocides against pest flies in the dung of treated cattle. Medical and Veterinary Entomology 15:117-120.

Floate, K. D., K. G. Wardhaugh, A. B. A. Boxall, and T. N. Sherratt. 2005. Faecal residues of veterinary pharmaceuticals: non-target effects in the pasture environment. Annual Review of Entomology 50:153-179.

Green, G. A., And R. G. Anthony. 1989. Nesting success and habitat relationships of burrowing owls in the Columbia Basin, Oregon. The Condor 91:347-354.

GrinneLL, J. 1983. Nesting of the road-runner. Science 24:247.

Hammer, 0. 1941. Biological and ecological investigations on flies associated with pasturing cattle and their excrement. Videnskabelige Meddelelser, Dansk Naturhistorisk Forening, København 105:1-257.

Haug, E. A., B. A. Millsap, and M. S. Martell. 1993. Burrowing owl (Speotyto cunicularia). In: A. Poole and F. Gill [EDS.]. The birds of North America, no. 61. Philadelphia, PA, and Washington, DC, USA: The American Ornithologists' Union and The Academy of Natural Sciences. 20 p.

Holroyd, G. L., R. Rodrigues-Estrella, and S. R. Sheffield. 2001. Conservation of the burrowing owl in western North America: issues, challenges, and recommendations. Journal of Raptor Research 35:399-407.

Horgan, F. G., AND S. D. Berrow. 2004. Hooded crow foraging from dung pats: implications for the structure of dung beetle assemblages. Biology and Environment: Proceedings of the Royal Irish Academy 104B:119-124.

Laurence, B. R. 1954. The larval inhabitants of cow pats. Journal of Animal Ecology 23:234-260.

Levey, D. J., R. S. Duncan, and C. F. Levins. 2004. Use of dung as a tool by burrowing owls. Nature 431:39.

LIM, B. K. 1987. Lepus townsendii. Mammalian Species 288:1-6.

LonghuRst, W. M. 1942. The summer food of burrowing owls in Costilla County, Colorado. Condor 44:281-282.

MARTI, C. D. 1974. Feeding ecology of four sympatric owls. The Condor 76:45-61.

McCracken, D. I. 1993. The potential for avermectins to affect wildlife. Veterinary Parasitology 48:273-280.

Michener, G. R., and J. W. Koeppl. 1985. Spermophilus richardsonii. Mammalian Species 243:1-8.

Moнr, C. 0. 1943. Cattle droppings as ecological units. Ecological Monographs 13:275-298.

Newstead, R. 1908. The food of some British birds. Journal of the Board of Agriculture XV 9(December):1-87.

Poulin, R. G., AND L. D. TodD. 2006. Sex and nest stage differences in the circadian foraging behaviours of nesting burrowing owls. The Condor 108:856-864. 
Poulin, R. G., L. D. Todd, K. M. Dohms, R. M. Brigham, and T. I. Wellicome. 2005. Factors associated with nest- and roost-burrow selection by burrowing owls (Athene cunicularia) on the Canadian prairies. Canadian Journal of Zoology 83:1373-1380.

Powell, G. L., And A. P. Russell. 1985. Growth and sexual size dimorphism in Alberta populations of the eastern short-horned lizard, Phrynosoma douglassi brevirostre. Canadian Journal of Zoology 63:139-154.

RICH, T. 1986. Habitat and nest-site selection by burrowing owls in the sagebrush steppe of Idaho. The Journal of Wildlife Management 50:548-555.

Schlatter, R. P., J. L. Yanez, H. Nunez, and F. M. Jaksic. 1980. The diet of the burrowing owl in central Chile and its relation to prey size. The Auk 97:616-619.

Sissons, R. A. 2003. Food and habitat selection of male burrowing owls (Athene cunicularia) on southern Alberta grasslands [M.Sc. thesis]. Edmonton, AB, Canada: University of Alberta. $92 \mathrm{p}$.

Smith, M. D., And C. J. Conway. 2007. Use of mammal manure by nesting burrowing owls: a test of four functional hypotheses. Animal Behaviour 73:65-73.

Statistics Canada. 2008. Cattle inventories, by province (Canada). Available at: http://www40.statcan.ca/101/cst01/prim50a.htm. Accessed 1 April 2008.
Steel, J. W., and K. G. Wardhaugh. 2002. Ecological impact of macrocyclic lactones on dung fauna. In: J. Vercruysse and R. S. Rew [EDS.]. Macrocyclic lactones in antiparasitic therapy. Wallingford, United Kingdom: CABI Publishing. p. 141-162.

Studier, E. H., and J. W. Procter. 1971. Respiratory gases in burrows of Spermophilus tridecemlineatus. Journal of Mammalogy 52:631-633.

Suarez, V. H., A. L. Lifschitz, J. M. Sallovitz, and C. E. Lanusse. 2008. Effects of faecal residues of moxidectin and doramectin on the activity of arthropods in cattle dung. Ecotoxicology and Environmental Safety (in press).

THOMSEN, L. 1971. Behavior and ecology of burrowing owls on the Oakland Municipal Airport. The Condor 73:177-192.

US Department of Agriculture. 2007. Cattle. July 1 cattle inventory down slightly. Available at: http://www.usda.gov/nass/PUBS/TODAYRPT/catl0707.pdf. Accessed 12 September 2007

Valiela, I. 1969. An experimental study of the mortality factors of larval Musca autumnalis DeGeer. Ecological Monographs 39:199-225.

Verts, B. J., and L. N. Carraway. 1999. Thomomys talpoides. Mammalian Species 618:1-11.

Wardhaugh, K. G., R. J. Mahon, and H. Bin Ahmad. 2001. Efficacy of macrocyclic lactones for the control of larvae of the Old World screw-worm fly (Chrysomya bezziana). Australian Veterinary Journal 79:120-124. 
Appendix I. Biomass of burrowing owl prey items and source of estimates.

\begin{tabular}{|c|c|c|}
\hline Taxa & Estimated weight $(\mathrm{g})$ & Source $^{1}$ \\
\hline \multicolumn{3}{|l|}{ Vertebrates } \\
\hline Peromyscus maniculatus & 20.0 & $n=1740$, RAM \\
\hline Microtus pennsylvanicus & 27.6 & $n=957$, RAM \\
\hline Lemmiscus curtatus & 20.7 & $n=14$, RAM \\
\hline Onychomys leucogaster & 28.8 & $n=20$, RAM \\
\hline Mus musculus & 18.3 & $n=117$, RAM \\
\hline Perognathus fasciatus & 9.8 & $n=36$, RAM \\
\hline Sorex haydeni & 2.4 & $n=210$, RAM \\
\hline Sorex montincolus & 5.6 & $n=96$, RAM \\
\hline Blarina brevicauda & 22.0 & $n=7, \mathrm{RSM}$ \\
\hline Spermophilus richardsonii & $76.0^{2}$ & $n=361$, Michener and Koeppl 1985 \\
\hline Lepus sp. & $90.0^{2}$ & Lim 1987 \\
\hline Thomomys talpoides & $65.0^{3}$ & Verts and Carraway 1999 \\
\hline Dipdomys ordii & 59.6 & $n=83$, RAM \\
\hline Zapus sp. (assumes Zapus princeps) & 24.4 & $n=224$, RAM \\
\hline Spermophilus tridecemlineatus & 72.2 & Studier and Procter 1971 \\
\hline Passeriformes (small) & 27.5 & average of two most common \\
\hline \multicolumn{3}{|l|}{ Horned lark (32.9 g, $n=77$, RAM) } \\
\hline \multicolumn{3}{|c|}{ Chestnut-collared longspur (22.1 g, $n=71$, RAM) } \\
\hline Anurans (assumes juvenile Bufo congnatus) & 15.0 & Bragg 1940 \\
\hline Ambystoma tigrinum & 15.4 & $n=6$, RAM \\
\hline Thamnophis radix & 50.2 & $n=62$, R. G. Poulin, unpublished data \\
\hline Phrynosoma hernandesi & 10.0 & Powell and Russell 1985 \\
\hline Unidentified Cricetidae & 22.0 & Sissons 2003 \\
\hline \multicolumn{3}{|l|}{ Invertebrates } \\
\hline Cambarus sp. & 6.5 & Craighead and Craighead 1956, cited in Marti 1974 \\
\hline Coleoptera & see Table 5 & Marti 1974 \\
\hline Acrididae (grasshoppers) & 0.6 & Marti 1974 \\
\hline Gryllidae (crickets) & 0.4 & Marti 1974 \\
\hline
\end{tabular}

